\title{
To Secede or Not Secede? Is It Even Possible?
}

\author{
T. Z. Cook \\ Indiana University Maurer School of Law, zachcook@indiana.edu
}

Follow this and additional works at: https://www.repository.law.indiana.edu/ijgls

Part of the Comparative and Foreign Law Commons, Constitutional Law Commons, International Humanitarian Law Commons, and the International Law Commons

\section{Recommended Citation}

Cook, T. Z. (2019) "To Secede or Not Secede? Is It Even Possible?," Indiana Journal of Global Legal Studies: Vol. 26 : Iss. 1 , Article 13.

Available at: https://www.repository.law.indiana.edu/ijgls/vol26/iss1/13

This Note is brought to you for free and open access by the Law School Journals at Digital Repository @ Maurer Law. It has been accepted for inclusion in Indiana Journal of Global Legal Studies by an authorized editor of Digital Repository@ Maurer Law. For more information, please contactrvaughan@indiana.edu.

\section{$\Psi$}

JEROME HALL LAW LIBRARY

INDIANa UNIVERSITY

Maurer School of Law
Bloomington 


\title{
To Secede or Not Secede? Is It Even Possible?
}

\author{
T. ZACHARY COOK*
}

\section{INTRODUCTION}

Secession seems like a concept of the past. In our increasingly globalizing world, nationalism was growing archaic and halting progress. But secession has seen a surge in the last ten years. Kosovo declared independence from Serbia in 2008. The United Kingdom seceded from the European Union in the infamous "Brexit." And in 2017, Catalonia's grab for independence sparked the worst crisis in Spain since the days of Francisco Franco. ${ }^{1}$ Alongside these high-profile secessions, smaller movements, which until now were simply brewing and bubbling, are becoming inspired. One such movement is "The South is My Country," a coalition of three southern Brazilian states that wish to secede from Brazil.

This paper will examine the Brazilian separatist movement. After introducing the movement and the history of modern Brazil in Part I, Part II will examine what Brazilian law has to say on secession with the Catalan crisis as a comparison. Part III will attempt to navigate the murky waters of international law to determine whether a group such as "The South is My Country" has a right to unilaterally secede.

\section{BRAZILIAN BACKGROUND}

\section{A. Highlights of Modern Brazilian History}

The past seventy years of Brazilian history are full of conflict, coups, and humanitarian issues. In 1954, the Vargas Era ended with Getúlio Vargas's suicide, and for the next ten years, the threat of a coup

\footnotetext{
* Articles Editor, Indiana Journal of Global Legal Studies, Volume 26; J.D. Candidate 2019, Indiana University Maurer School of Law; B.A. 2016, Taylor University.

1. See Angela Dewan, Catalonia Decides: Spain's Trouble Region Votes in Knife-Edge Election, CNN (Dec. 21, 2017, 3:52 PM), http://www.cnn.com/2017/12/21/europe/cataloniaelection-day-spain-independence-intl/index.html.
}

Indiana Journal of Global Legal Studies Vol. 26 \#1 (Winter 2019)

(C) Indiana University Maurer School of Law 
loomed over Brazil's leadership. ${ }^{2}$ In 1964 that threat became a reality. Growing dissatisfaction with President João Goulart, a far leftist, prompted the military to take control of the government and create a dictatorship. ${ }^{3}$ From the military's perspective, it was finally correcting its recurring error of withdrawing troops before a coup created lasting change. ${ }^{4}$

Under the military-appointed presidents, the Brazilian government cracked down hard on leftism. The dictatorship was overtly anticommunist and treated prior left-leaning leaders as personae non gratae. ${ }^{5}$ The government preached undying loyalty, suspended habeas corpus, and institutionalized torture of political undesirables (with help from the United States, no less). ${ }^{6}$ The Brazilian Catholic Church uncovered details about the dictatorship's actions. They found that onethird of the people the government arrested were students, labor activists, clergymen, and journalists. ${ }^{7}$ And yet, many Brazilians were willing to put up with the dictatorship's abuses in exchange for the stability and economic gains it achieved. ${ }^{8}$

The dictatorship began to wane in the mid-1970s during the term of President General Ernesto Geisel. ${ }^{9}$ Frustrated by the difficulty of maintaining the dictatorship, the armed forces announced they would gradually restore civilian government. By 1985, civilians were fully in control of the government once more. ${ }^{10}$ The constitution that Brazil currently uses was created in 1988; however, this constitution has a dissonance between the ideals it sets for Brazil and the practical application of those ideals.

As Teresa Meade, author of A Brief History of Brazil, puts it, "On paper, the 1988 Constitution is one of the most far-reaching progressive documents passed by any government." 11 She has ample reason to think so. Article 5 of the constitution proclaims, among many other things: equality before the law, equal rights for men and women, freedom of speech, freedom of religion, a right to privacy, and a right to be free from torture. ${ }^{12}$ Articles 6 and 7 set out social and labor rights, including

\footnotetext{
2. Robert M. Levine, The HiStory of BRAZIL 122 (1999).

3. Id. at 124-26.

4. Id. at 127 .

5. Id.

6. Id. at 129 .

7. Id. at 135 .

8. Id. at 136 .

9. $I d$.

10. Id.

11. Teresa A. Meade, A Brief History of Brazil 178 (2d ed. 2010).

12. Constitution of the Federative RePublic of Brazil, Oct. 5, 1988, tit. I, art. 5.
} 
education and social security, ${ }^{13}$ paid maternity and paternity leave, and non-discrimination in wages. ${ }^{14}$ In general, the constitution weakened the executive branch while strengthening the legislative and judicial branches. ${ }^{15}$

However, in practice, this progressive constitution does not go very far. The constitution was written by 559 members of the Brazilian Congress and, as a result, is better at exhibiting diverse thought than it is at being an effective instrument of government. ${ }^{16}$ The variety of goals and opinions in Congress created fragmentation that crippled Congress's ability to implement the broad economic and social policies of the constitution; now, only the weakened executive can effectively carry those out. ${ }^{17}$ In addition, the constitution lacks checks and balances. ${ }^{18}$ Ultimately, the old political system remained in place, which created more opportunities for corruption and hindered the social change that the constitution sought. 19

\section{B. What is "The South is My Country?"}

The separatist movement known as "The South is My Country" got its start in 1992 in the state of Santa Catarina. ${ }^{20}$ The movement's chief grievances were a lack of representation in the Brazilian Congress, government corruption, uneven taxation, and unemployment. ${ }^{21}$ The movement's stance has not changed in its twenty-five years of existence. The group's goal is for the three southernmost states of Brazil-Paraná, Santa Catarina, and Rio Grande do Sul-to secede from the nation of Brazil and form their own country.

While Paraná and Santa Catarina are tied to the movement, Rio Grande do Sul has historical precedent for the movement. Rio Grande do Sul is very close to Uruguay and Argentina, which made it a buffer zone between the Spanish and Portuguese Empires during their

13. Constitution of the Federative Republic of BraziL, Oct. 5, 1988, tit. I, art. 6.

14. Constitution of the Federative Republic of Brazil, Oct. 5, 1988, tit. I, art. 7.

15. Meade, supra note 11 , at 178 .

16. Id.

17. LEVINE, supra note 2, at 151 .

18. Id.

19. Id. at $138-39$.

20. Paula Sperb, In Informal Referendum, 95\% Vote for the Separation of the South Region from the Rest of Brazil, FOLHA DE S. PAULO (Oct. 5, 2016, 11:05 AM), http://www 1.folha.uol.com.br/internacional/en/brazil/2016/10/1820048-in-informalreferendum-95-vote-for-the-separation-of-the-south-region-from-the-rest-of-brazil.shtml.

21. See NowThis World, Could South Brazil Become Its Own Country?, YouTuBE (Oct. 24, 2016), https:/www.youtube.com/watch?v=rnZ1cvQnUTk. 
conquests of South America. ${ }^{22}$ In 1835, the Farroupilha Revolution broke out, a revolt sparked by, of all things, the beef jerky trade. ${ }^{23}$ Aided by the Italian revolutionary Giuseppe Garibaldi, Rio Grande do Sul was able to achieve independence for a short while, ${ }^{24}$ until the revolutionaries surrendered in $1845 .{ }^{25}$ While it was ultimately defeated, the people of Rio Grande do Sul's capital city, Porto Alegre, hold strong nostalgic feelings for the event. 26

"The South is My Country," like the Farroupilha Revolution before it, has an economic component to it. The region is prosperous; it has a Human Development Index of 0.83 , which is significantly higher than Brazil's score and in the realm of Chile, the highest scoring country in Latin America. ${ }^{27}$ This prosperity is reflected in the region's taxation. The northeastern Brazilian state of Bahia pays less than half of the federal taxes that Rio Grande do Sul pays despite having a much larger population. ${ }^{28}$ For "The South is My Country," that inequality is part of the problem.

The separatists also claim that southern Brazil is culturally distinct from the rest of Brazil. While most of Brazil is a melting pot of African, Asian, European, and indigenous peoples, the southernmost states are considerably more European. ${ }^{29}$ These three states have a history of German, Italian, and Slavic immigration, ${ }^{30}$ to the point that almost 80 percent of the population is ethnically European. ${ }^{31}$ Several southern cities speak German and hold German traditions, such as the renowned Oktoberfest. ${ }^{32}$ This cultural distinction may play a part in the separatist movement's feeling that the Brazilian government is unfairly overrun with representatives from the northeast and Amazon regions. ${ }^{33}$ As one southerner put it, "If you hear the accent of the political legislature of Brazil it is a north-eastern one." 34

22. See Gerald Lynch, Insight | No Country for Southern Men, WIDE ORBITS (Jan. 12, 2017), http://wideorbits.com/life/no-country-for-southern-men/.

23. In fairness to the people of 1800 s Rio Grande do Sul, American colonists started an uprising over tea about sixty years prior.

24. BBC, Brazilians in the South asked to vote on secession, 8 October 2017, http://www.bbc.com/news/world-latin-america-41541063 [hereinafter Brazilians]; Lynch, supra note 22 .

25. Lynch, supra note 22.

26. See id.

27. Id.

28. NowThis World, supra note 21.

29. Id.

30. See Lynch, supra note 22.

31. NowThis World, supra note 21.

32. Id

33. Id.

34. Brazilians, supra note 24. 
This feeling of disunity ties in to Brazil's perspective on citizenship and rights. For many Brazilians, citizenship and rights depend on relationships. ${ }^{35}$ Being a Brazilian citizen means knowing your place; "he doesn't know his place" is considered an insult. ${ }^{36}$ However, due to the complications and inefficiencies of the 1988 constitution, Brazil has not applied the rights of its citizens universally, which may cast doubt on exactly what a person's place is. ${ }^{37}$ Many young Brazilians see rights as something earned by conforming to the expectations of the majority; in other words, citizenship does not grant rights, it is merely a sign that you have rights. ${ }^{38}$ Influential citizens are given softer punishments for breaking the law. ${ }^{39}$ Citizens who fall lower on the social ladder are ambivalent about their relationship to the state, and Brazil's history of aggressive and harmful patriotism during the military dictatorship does not assuage those concerns. ${ }^{40}$ Given the social, economic, and cultural differences between the southern states and the rest of Brazil, it is reasonable to say that the southerners are concerned about their rights and their place in the system. If that is the case, it is no wonder that some southerners wish to strike out on their own.

\section{THE CATALAN CONNECTION: LAWS OF THE STATE}

Catalonia's quest for independence is a long-running one. Catalonia was a territory in Aragon that became part of Spain upon the marriage of Ferdinand and Isabella in $1453 .{ }^{41}$ At first, Catalonia remained autonomous, but in 1716 , its status as a state was completely revoked following the War of Spanish Succession. ${ }^{42}$ Francisco Franco's rule did nothing to help Catalan matters. In fact, Franco did quite the opposite: Catalonians were forbidden from speaking their native language or expressing any cultural identity. ${ }^{43}$ It was not until after the Franco regime that Catalan autonomy was brought back as a concept. The 1978 Spanish Constitution and the 1979 Statute of Autonomy restored both Spanish democracy and Catalan autonomy, but the region has been

35. LEVINE, supra note 2 , at 153 .

36. Id. at 154 .

37. Id. at $153-54$.

38. Id. at 156 .

39. Id. at 154 .

40. Id. at 156 .

41. Thomas Y. Patrick, Note, The Zeitgeist of Secession Amidst the March Towards Unification: Scotland, Catalonia, and the Future of the European Union, 39 B.C. INT'L \& COMP. L. REV. 195, 202 (2016).

42. Id.

43. Maria Garcia Barcia, Note, Catalonia: The New European State?, 20 ILSA J INT'L \& COMP. L 399, 400-401 (2014). 
craving full independence ever since. ${ }^{44}$

Catalonia's attempt to secede from Spain is relevant here for two reasons. First, Catalonia's situation shares important similarities with "The South is My Country," although the situations are not perfect parallels. Second, the resurgence of The South is My Country" seems to be linked to Catalonia's October 2017 referendum. ${ }^{45}$ The timing and similarity of both referendums points to "The South is My Country" being inspired by Catalonia.

\section{A. A Brief Overview of the Catalan Crisis ${ }^{46}$}

In 2006, Spain passed a statute giving Catalonia much more power and autonomy, even defining it as a nation, but this was revoked by the Spanish government in 2010. ${ }^{47}$ Economic downturns exacerbated Catalonian unrest. Catalonia was yet another victim of the 2008 stock market crash, ${ }^{48}$ and by 2014 , Catalonia's unemployment rate jumped to 24.45 percent, with 43 percent youth unemployment. ${ }^{49}$ Some Catalonians espoused the feeling that the Spanish government was taking far more than it was giving. In 2014, Catalonia paid roughly $€ 10$ billion more to the central government than it received. ${ }^{50}$ In addition, Spain's investment in Catalonia has dropped from 16 percent of the national budget in 2003 to 9.5 percent in $2015 .{ }^{51}$

In October of 2017, the Catalonian Parliament held an illegal referendum, asking the people whether they wanted to secede from Spain. ${ }^{52}$ Of the 43 percent of Catalonians who voted, 90 percent backed independence. ${ }^{53}$ The referendum attracted additional attention from the attempted suppression of voters that involved a use of force eerily reminiscent of the Franco days. ${ }^{54}$ Bolstered by the referendum's results, the Catalonian Parliament declared independence from Spain on

44. Patrick, supra note 41 , at 203.

45. See BBC, Catalonia Crisis in 300 Words (June 2, 2018), http://www.bbc.com /news/world-europe-41584864 [hereinafter Catalonia 300]; see also LYNCH, supra note 22.

46. For a more detailed examination of the crisis before 2017 , see generally Barcia, supra note 42 .

47. BBC, From Autonomy to Independence: Catalonia's Bid for Independence from Spain via Parliamentary Democracy, THE ETHIOPIA OBSERVATORY https:/ethiopia observatory.com/2017/12/25/from-autonomy-to-independence-catalonias-bid-for-

independence-from-spain-via-parliamentary-democracy/ [hereinafter Catalonia's Bid].

48. See id.

49. Patrick, supra note 41, at 203.

50. Catalonia's Bid, supra note 48.

51. Id

52. Dewan, supra note 1.

53. Catalonia 300, supra note 45.

54. See Catalonia's Bid, supra note 47; see also Dewan, supra note 1. 
October 27, 2017.55

The Spanish government, understandably, did not take this well. Prime Minister Mariano Rajoy invoked Article 155 of the Spanish Constitution, ${ }^{56}$ which allows the Spanish government to take necessary measures to ensure that an autonomous region complies with government interests. ${ }^{57}$ The government sacked the leaders of the Catalonian Parliament and called for a snap election in hopes of creating a new Catalonian government that disfavored independence. ${ }^{58}$

The Spanish government's hopes were dashed. No single party won enough seats for a majority, and the pro-independence parties had a combined majority despite receiving only 8 percent of the popular vote. ${ }^{59}$ But with Catalonian authority revoked via Article 155 , the unionist Popular Party-despite receiving 4 percent of the vote-is in control of the region until a coalition government can be established. 60 The most likely outcome is that the pro-independence parties will form a coalition government, which will put the Spanish government back to square one. 61

\section{B. Comparing and Contrasting the Secession Movements}

In many ways, the independence movements in Catalonia and southern Brazil are very similar. To begin with, both regions are wealthy, especially when compared to the rest of their respective countries. Both regions feel that their governments are requiring them to pay out far more than the regions receive. Also, both movements have utilized illegal referendums to gauge their populations' interest in secession. As we shall see in the next section, both regions are faced with similar constitutional challenges to their prospective secessions, neither of which looks particularly promising. And finally, both regions

55. Catalonia's Bid, supra note 47

56. "If an Autonomous Community does not fulfil the obligations imposed upon it by the Constitution or other laws, or acts in a way seriously prejudicing the general interests of Spain, the Government . . . may, following approval granted by an absolute majority of the Senate, take the measures necessary in order to compel the latter forcibly to meet said obligations, or in order to protect the above-mentioned general interests." SPANISH Constitution, Dec. 27,1978 , art. 155 , para 1.

57. See generally Catalonia's Bid, supra note 47 (illustrating cases in which the constitutional court took measures to limit Catalonian independence).

58. Catalonia 300 , supra note 45.

59. Sebastiaan Faber \& Bécquer Seguin, Catalonia's Elections Take Spain Back to Square One, THE NATION (Dec. 29, 2017), https://www.thenation.com/article/cataloniaselections-take-spain-back-to-square-one/.

60. Id.

61. Id. 
have a culture, ethnicity, and language different from the rest of their respective countries.

However, the differences between the movements are important. With the suppression of voters during the October 2017 referendum, pro-independence Catalans have evoked the specter of Francisco Franco and all the human rights baggage that accompanies him. By contrast, despite Brazil's recent history of human rights abuses, "The South is My Country" has not faced the kind of suppression that Catalan secession has. Part III demonstrates that the presence or lack of human rights issues can be an important factor in secession at the international level. Another international-level difference is that, should Catalonia's bid for independence be successful, the nation will have to deal with European Union membership (or lack thereof) in addition to United Nations membership and international recognition. Although still significant hurdles, "The South is My Country" need only worry about membership in the United Nations and international recognition.

\section{Constitutional Challenges to Secession}

Before examining the prospects of secession at the international level, it is prudent to look at Brazil and Spain's approaches to secession. Title I, Article I of the Brazilian Constitution refers to the states as an "indissoluble union." 62 With very little else to say on the matter, the Brazilian Constitution seems to shut the door on secession. ${ }^{63}$ Theoretically, the constitution could be changed to allow secession. Title II, Article 14 provides that, "[t]he sovereignty of the people shall be exercised by universal suffrage, and by direct and secret voting, with equal value for all, and, according to the law, by means of (I) plebiscite; (II) referendum; (III) people's initiative." ${ }^{4}$ However, this requires both popular support and an acknowledgment from the Brazilian government, and "The South is My Country" has neither.

The Brazilian government forbade "The South is My Country" from referring to its referendums as "plebiscites" for fear that the legal implications of the term would give voters the wrong idea. ${ }^{65}$ In addition, the organizers of the referendum were forbidden from holding the vote

62. Constitution of the Federative Republic of Brazil, Oct. 5, 1988, tit. I, art. 1.

63. See Sperb, supra note 20 (interpreting the constitution to mean separation is illegal under title I, article 1); see also Lynch, supra note 22 (interpreting the constitution to mean secession is illegal); see also Brazilians, supra note 24 (stating secession is forbidden under the constitution).

64. Constitution of the Federative Republic of Brazil, Oct. 5, 1988, tit. II, art. 14.

65. Lynch, supra note 22 . 
on the same day as a municipal election. ${ }^{66}$ Therefore, it is unwise to assume that the recent referendums in Brazil were anything other than experimental. Fortunately, "The South is My Country" seemed to accept that. The informal nature of its most recent referendum (organized roughly one week after Catalonia's October 2017 vote) suggests that "The South is My Country" only wishes to gauge citizens' interest in secession. ${ }^{67}$

"The South is My Country's" other concern is support. While 95.75 percent of the referendum voted in favor of secession, ${ }^{68}$ that figure is deceptively large. Only 617,543 people participated in the referendum, so 95 percent of voters, in this case, is about 3 percent of southern Brazil.69 Given these factors, the likelihood of "The South is My Country" ever getting far enough in the secession process to worry about United Nations membership and international recognition is very low.

Catalonia does not fare much better. Like Brazil, Spain's constitution refers to its territories and states as an "indissoluble unity."70 That same article generously guarantees autonomy of its various regions. ${ }^{71}$ Additional provisions under Part IX of the constitution allow regions such as Catalonia to pass statutes of autonomy, but not declare independence. ${ }^{72}$ Like "The South is $\mathrm{My}$ Country," Catalonia lacks popular support, though not to the extent of the Brazilian movement. Many Catalans are satisfied with autonomy; they see being a cultural nation as more important than being a sovereign nation. ${ }^{73}$ In fact, Michael J. Kelly, author of Political Downsizing: The Re-Emergence of Self-Determination, and the Movement Towards Smaller, Ethnically Homogenous States, suspects that relinquishing more autonomy for the region might quell the separatist elements altogether. ${ }^{74}$

Here ends the analysis of what is. For many international players, this is as far as is necessary to go. But this paper has the ambition to go beyond what is and venture into the realm of what could be. For the sake of further discussion, let us assume that "The South is My Country" (and Catalonia) seceded, regardless of Brazil's or Spain's laws.

66. Id.

67. Brazilians, supra note 24 .

68. Sperb, supra note 20 .

69. Id.

70. SPANISH CONSTITUTION, Dec. 27, 1978, prelim. part, art. 2.

71. $I d$.

72. See Spanish Constitution, Dec. 27, 1978, art. 134-48.

73. Michael J. Kelly, Article: Political Downsizing: The Re-Emergence of SelfDetermination, and the Movement Towards Smaller, Ethnically Homogenous States, 47 Drake L. Rev. 209, 232 (1999).

74. See id. 
What would await them on the international stage? What legal hurdles would "The South is My Country" have to overcome, and what are the odds of it doing so? The next section of this paper seeks to answer those questions.

\section{INTERNATIONAL LAW ON SECESSION}

To say that international law is ambiguous about secession is a gross understatement. The United Nations Charter has no explicit rule affirming or denying a right to secede. ${ }^{75}$ The subject has proven to be too complicated for a general, bright-line rule, and so the United Nations appears to tolerate ambiguity in this field of international law. ${ }^{76}$ Even the concept of secession, particularly its ties to other concepts of international law such as self-determination and international recognition, is complicated. To make the discussion of international law as simple as possible, the first point will focus on the applicability of international law to non-states.

\section{A. What is Subject to International Law?}

There is a debate as to whether non-states are covered by international law. Scholars such as Michael J. Kelly argue that such entities are not covered. International law, Kelly claims, is based on how nation-states relate to each other. ${ }^{77}$ Sub-states (minority groups within a state) do not take part in this relationship, and therefore, international law is not the forum in which they should speak. ${ }^{78}$ Furthermore, the International Court of Justice has not recognized a sub-state's claim for self-determination. ${ }^{79}$ In a strange twist, not being covered by international law could mean that secession does not violate international law, and the group seceding would not be covered by it. ${ }^{80}$ However, in its decision on Kosovo, the International Court of Justice made it clear that declarations of independence could violate

75. Reference re Secession of Quebec, 37 Int'l Legal Materials 1340 (Can. 1998), in Mark Weston Janis \& John E. Noyes, InTERnAtional LAw: CASES AND Commentary 521 (4th ed. 2010) [hereinafter Janis \& Noyes]

76. John Dugard, A Legal Basis for Secession-Relevant Principles and Rules, in

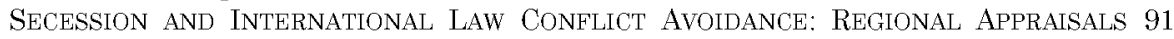
(Julie Dahlitz, ed., 2003).

77. Kelly, supra note 73 , at 222.

78. $I d$.

79. Id.

80. Marc Weller, Escaping the Self-Determination Trap 15 (2008). 
international law. ${ }^{81}$

On the other side of the debate, scholars such as Christopher O. Quaye argue that statehood is not required to be covered by international law. United Nations covenants from 1966 emphasize individual rights such as freedom of speech and a right to education; why protect individual rights if individuals are not covered by international law? ${ }^{2}$ Quaye also notes the focus on individuals in cases such as the Nuremberg Trials and United States $v$. Smith, 18 U.S. 153 (1820), 83 to support his argument. ${ }^{84}$ Finally, Quaye adds that the 1970 Declaration on Friendly Relations clearly provides that the legal concept of self-determination may apply to secessions but qualifies his point with the fact that this declaration is not absolute. 85

Another question arises from the use of the word "peoples." Article 1(2) of the United Nations Charter provides that one purpose of the United Nations is "to develop friendly relations among nations based on respect for the principle of equal rights and self-determination of peoples." 86 What exactly is meant by the word "peoples?"

There are two schools of thought on the answer to this question. The first, led by Emerson and Eagleton, claims that "peoples" refers to colonized peoples. ${ }^{87}$ This definition will be important later, as secessions in the colonial context are treated differently than secessions outside that context. 88 Quaye argues that this interpretation of "peoples" nullifies the use of the word elsewhere in the charter and several other United Nations documents. ${ }^{89}$ Quaye also notes that general literature is neither silent nor totally supportive of this interpretation. ${ }^{90}$

The second school of thought is led by Chowdhury and Nayar. They claim that "peoples" refers to all peoples, within or without a State. ${ }^{91}$ In addition, the beneficiaries of self-determination are the people themselves, within a defined territory (not the territory they belong

81. Theodore Christakis, The ICJ Advisory Opinion on Kosovo: Has International Law Something to Say About Secession?, LEIDEN J. INT'L L. 73, 73 (2011).

82. Christopher O. QuaYe, Liberation STRUgGLes In INTERnational LaW 49 (1991).

83. In United States $v$. Smith, the Supreme Court of the United States was asked to determine whether the crew of a ship called The Creollo committed piracy. The Court found that the defendants had committed piracy "as defined by the law of nations." Smith at 183 .

84. Id. at 48 .

85. Id. at 33 .

86. U.N. Charter art. 1, 2 .

87. QUAYE, supra note 82 , at 218.

88. Janis \& Noyes, supra note 75 , at 521.

89. QUAYE, supra note 82 , at 218 .

90. Id. at 222 .

91. Id. at 219 . 
to). ${ }^{92}$ Accordingly, the principle of self-determination has universal application. ${ }^{93}$

While each view has its proponents and support, the United Nations seems to lean toward the Emerson/Eagleton interpretation. As we will see later, the United Nations recognizes three main limits to secession and self-determination. One of those limits is that "peoples" refers to all the people in a state, as opposed to ethnic groups. ${ }^{94}$ This limit goes against the Chowdhury/Nayar interpretation because it does not account for subdivisions of a nation's population the way that Chowdhury and Nayar do.

\section{B. What is Self-Determination?}

The concept of self-determination is deeply entwined with issues of secession to the point where it is very difficult to discuss one without the other. Some believe that this should not necessarily be the case. Scholars such as Marc Weller argue that it is possible for a new state to come into being via secession without having a right to selfdetermination. ${ }^{95}$ However, a state that comes into being through mere effectiveness (de facto but not de jure) may face forced reincorporation into the original state. ${ }^{96}$

Self-determination is hard to define, partially because different groups mean different things by it. In the early 1900s, selfdetermination was closely tied to independent states rising from the ashes of the Ottoman and Austro-Hungarian Empires in the wake of World War I. ${ }^{97}$ In the mid-1900s, it meant independence for previously colonized nations. ${ }^{98}$ Toward the end of the century, self-determination came to mean one of three things: independence for states emerging from the collapse of the Soviet Union, independence for homogenous sub-units within states, or greater internal autonomy for smaller subunits within states. 99 Today, the international community agrees that some form of self-determination exists, but it has yet to give it a significant meaning in the post-colonial context. ${ }^{100}$

Self-determination can be viewed through two other lenses:

92. $I d$.

93. Id.

94. Dugard, supra note 76 , at 92.

95. WELLER, supra note 80, at 15.

96. $I d$. at 16 .

97. See Kelly, supra note 73 , at 221.

98. Id.

99. Id.

100. Id. at 220 . 
internal and external. A right to internal self-determination refers to provincial autonomy within an existing state, and the political, civil, and social rights that accompany that autonomy. ${ }^{101}$ External selfdetermination refers to the right to separate from an existing state to form a new, independent state. ${ }^{102}$ Woodrow Wilson championed this view of self-determination, although his view of external selfdetermination was freedom from foreign rule. ${ }^{103}$

Finally, there is the matter of how the United Nations Charter Article 1(2) refers to self-determination. The way the United Nations uses the word is not necessarily the layman's way. ${ }^{104}$ According to James Crawford, a professor of international law at the University of Cambridge, the United Nations' use of the word can have one of two meanings. The first is the right of the people of a state to choose their own form of government without external intervention. ${ }^{105}$ The second meaning is the right of a specific territory to choose its form of government irrespective of the rest of the state's wishes. ${ }^{106}$ According to Crawford, the United Nations Charter gravitates toward the first definition. ${ }^{107}$ Although the second definition may be implicitly supported elsewhere in the charter, United Nations resolutions that declare that definition-such as the Friendly Relations Declaration-overstep their bounds in doing so. 108

From these numerous approaches, we may synthesize a working definition of self-determination. From Kelly's article, we can gather that self-determination has a different meaning depending on the context in which it arises. The three scenarios Kelly lists - emerging from the collapse of a larger state, independence for sub-states, and autonomy for sub-states - can fit into the subcategories of internal and external selfdetermination. The first two scenarios can be considered external selfdetermination, and the last scenario can be considered internal selfdetermination. ${ }^{109}$ The United Nations Charter's uses of the term also fit into the "internal vs. external" dynamic. But Crawford's observation

101. Milena Sterio, On the Right to External Self-Determination: "Selfistans," Secession, and the Great Powers' Rule, 19 MiNN. J. INT'L L. 137, 145 (2010).

102. Id.

103. Janis \& Noyes, supra note 75 , at 514 .

104. Judge Rosalyn Higgins, Self-Determination and Succession, in SECESSION AND InTERnATIONAL LAW CONFLiCT AVOIDANCE: Regional APPRAiSALS 21, 24 (Julie Dahlitz, ed., 2003) [hereinafter Higgins].

105. James Crawford, The Creation of States in International LaW 114 (2d ed. 2006).

106. Id.

107. $I d$.

108. See id.

109. Kelly, supra note 73 , at 221-22. 
adds the insight that the United Nations, and international law by extension, focuses primarily on external self-determination.

The "internal vs. external" dichotomy of self-determination is the best way to think of the concept considering the various interpretations. Traditionally, external self-determination has been the focus of international law.

\section{Self-Determination and Secession}

Now that we have a less abstract concept of self-determination, we can properly examine its relationship to secession. Secession, in contrast to self-determination, is much easier to define: unilateral withdrawal of part of an existing state from the rest of that state, without the original state's consent. ${ }^{110}$

Does the right to self-determination come with a right to secession? Just as international law provides no explicit definition of selfdetermination, it is also silent on a right to secession. ${ }^{111}$ Why does it matter? According to Marc Weller, "an entity that can invoke the right to self-determination can secede, and it is legally privileged during that process." 112 Weller notes that secession without self-determination is possible but does not provide the privilege that self-determination does. ${ }^{113}$ Thus, whether or not a seceding sub-state has a right to selfdetermination can make a massive difference on its success. In practice it appears, however, that the likelihood of a sub-state having the right to secede depends almost entirely on which variety of self-determination is being sought.

External self-determination tends to give clearer results. This is the type of self-determination used in the aftermath of World War I, and later in the decolonization period. In determining whether Quebec had a right to secede from Canada, the Canadian Supreme Court stated that a right of secession in a colonial context has been accepted by international law. ${ }^{114}$ The Canadian court identified two scenarios where a right to self-determination and secession may exist outside the colonial context. The first scenario is alien subjugation, domination, or exploitation. ${ }^{115}$ This position is backed by the Declaration on Friendly Relations, which provides in relevant part: "subjugation of peoples to alien subjugation, domination and exploitation constitutes a violation of

\footnotetext{
110. Dugard, supra note 76 , at 89 .

111. Janis \& Noyes, supra note 75 , at 112.

112. WELLER, supra note 80 , at 15.

113. Id.

114. Janis \& Noyes, supra note 75 , at 521 .

115. Id.
} 
the principle, as well as a denial of fundamental human rights, and is contrary to the Charter." 116

The second scenario is when a people is blocked from exercising internal self-determination in a meaningful way. ${ }^{117}$ In this respect, a sub-state is entitled to secession only if the mother state refuses to respect the right to internal self-determination. ${ }^{118}$ The Canadian court found that the Vienna Declaration gave some support to this option by requiring that governments "represent the whole people belonging to the territory without distinction of any kind." 119

With the end of most colonies, these two non-colonial scenarios are the most likely outcomes for sub-states seeking a right of secession. Unfortunately, non-colonial movements are not afforded the privilege that comes with the colonial context; in fact, the opposite appears to be true. ${ }^{120}$ This presumption against secession resonates with Emerson and Eagleton's view that "peoples" refers to "colonized peoples." In their eyes, the right to self-determination, and any secession rights that came with it, ended along with colonization. ${ }^{121}$

However, as stated above, the United Nations tolerates the ambiguity surrounding this field of law. It also waffles on the issue. In some cases, such as Katanga and the Turkish Republic of Northern Cyprus, the United Nations has condemned secession. ${ }^{122}$ In other cases, such as Biafra and Bangladesh, the United Nations simply looked the other way. ${ }^{123}$ In fact, the United Nations has even "rewarded" the following seceding states with membership: Bangladesh, Eritrea, Israel, and the nations rising out of Yugoslavia. ${ }^{124}$ The United Nations has allowed secessions to occur, implying it does not view secession as inherently illegal ${ }^{125}$ —or at least that it does not consistently think so. In addition, the Committee on Human Rights has fostered the idea that self-determination may still apply outside the colonial context, and it appears that the idea is slowly gaining ground. ${ }^{126}$

The United Nations seems to recognize three limits to secession. The first limitation is the rule of territorial integrity. United Nations

116. $I d$.

117. Id.

118. Sterio, supra note 101, at 145-46.

119. Janis \& Noyes, supra note 75 , at 521 .

120. See WELLER, supra note 80, at 17.

121. QUAYE, supra note 82 , at 218 .

122. Dugard, supra note 76 , at 91 .

123. Id.

124. Id. According to Dugard, Israel could be considered a secession from the mandated territory of Palestine. Id.

125. See id.

126. Higgins, supra note 104 , at 29 . 
General Assembly Res. 1514(XV), paragraph 6, states any attempt aimed at the disruption of partial or total territorial integrity is incompatible with the United Nations Charter. ${ }^{127}$ Interestingly, the International Court of Justice, in its advisory opinion on Kosovo, controversially stated the rule of territorial integrity was confined to relations between states, which implied sub-states were not bound by the rule. 128 The second limitation is that, for the purposes of the United Nations Charter, "peoples" refers to all people in a state as opposed to the various ethnic groups in that state. ${ }^{129}$ Thus, ethnic minorities do not have the right to self-determination, and by extension, secession. ${ }^{130}$ Third and finally,the United Nations is generally more open to secession when the people wishing to secede are oppressed by their mother state. ${ }^{131}$

This muddled international legal theory results in a strong presumption against a right of secession existing when issues of internal self-determination arise. ${ }^{132}$ This presumption is fueled by concerns for territorial integrity: a fear that the number of ethnic conflicts would increase if a general right to secede was made explicit and that premature recognition of a seceding state would offend the mother state's sovereignty. ${ }^{133}$

\section{Overcoming the Presumption}

The presumption against a right of secession is strong, but rebuttable. Fortunately, the method of rebuttal is relatively simple compared to the previous questions in this paper. The most effective way to rebut the presumption against secession is to gain international recognition. Weller claims a state can secede without a right to selfdetermination because the existence of a state is a matter of fact. ${ }^{134}$ Effective existence is a classic criterion of statehood; even if it were a matter of law, it has been denied that criteria other than effectiveness exists. ${ }^{135}$ In fact, it is not even certain that self-determination is a

127. Dugard, supra note 77 , at 92

128. Christakis, supra note 81 , at 84 .

129. Dugard, supra note 76 , at 92 .

130. Id. at $92-93$.

131. Id. at 93 .

132. See id.; see also Malcom N. Shaw, The Role of Recognition and Non-Recognition with Respect to Secession: Notes on Some Relevant Issues, in SECESSION AND InTERnational LaW CONFLiCt AVOIDANCE: Regional APPRAisals 243, 247 (Julie Dahlitz, ed., 2003) [hereinafter Shaw].

133. Shaw, supra note 132 , at 247.

134. WELLER, supra note 80 , at 15 .

135. CRAWFORD, supra note 105 , at 97. 
criterion for statehood. ${ }^{136}$ Despite that bold proclamation, recognition is a way to achieve self-determination and statehood, especially considering the lack of explicit rule on the former. ${ }^{137}$

The Montevideo Convention lists four criteria for achieving statehood: a defined territory, a permanent population, a government, and the capacity to enter into international relations. ${ }^{138}$ None of these criteria are absolute. Some states, such as Israel, have disputed their borders for years and do not have a defined territory. ${ }^{139}$ Refugee crises have dramatically shifted populations in states such as Iraq and Sudan. ${ }^{140}$ Afghanistan did not have a stable government during the 1990s. ${ }^{141}$ And some very small nations, such as Monaco and various Pacific islands, have depended on nearby states for defense and trade. ${ }^{142}$ Yet none of the above examples resulted in a loss of statehood. ${ }^{143}$ The variable nature of these criteria has likely led other scholars to believe these criteria, while still necessary, are insufficient. ${ }^{144}$ In response, they have considered additional requirements, such as independence, willingness to observe international law, and, in some cases, recognition. ${ }^{145}$ Because of the inconsistency of how the criteria are satisfied, it may be best to think of them as factors rather than elements. It should also be noted that statehood is not recognition, but recognition can help achieve statehood.

Another avenue for recognition is to become a member of the United Nations. United Nations membership is open to "all peace-loving States that accept the obligations contained in the United Nations Charter and, in the judgment of the Organization are able to carry out these obligations." 146 'This is a fairly broad requirement, but the final decision is up to the General Assembly.

The process is relatively simple. First, the prospective member submits an application to the Secretary General along with a letter formally stating that the state accepts the obligations of membership. ${ }^{147}$ Second, the Security Council considers the application. Nine out of the

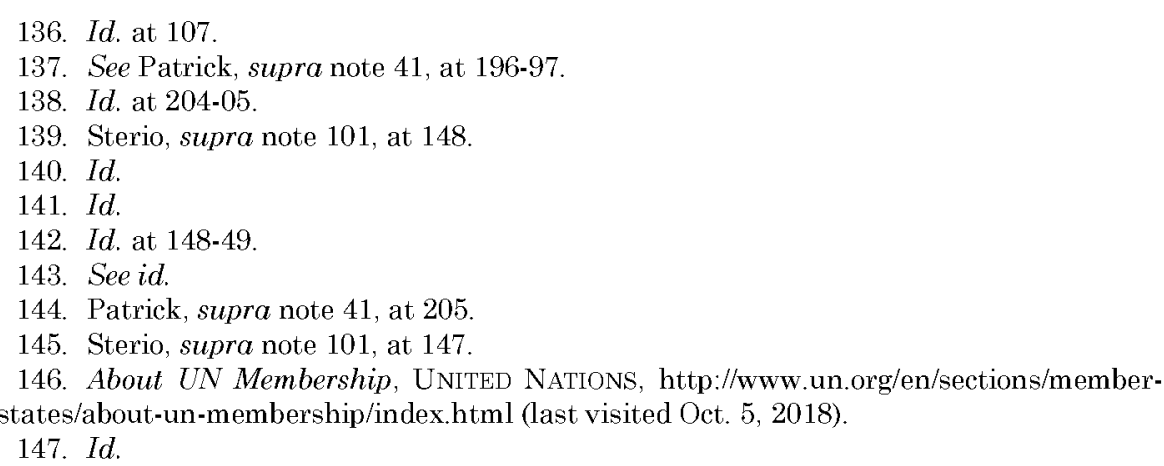


fifteen members must vote in favor, and none of the five permanent members-China, France, Russia, the United Kingdom, and the United States - must vote against the state. ${ }^{148}$ If the Security Council approves, it makes a recommendation to the General Assembly. ${ }^{149}$ If two-thirds of the assembly vote in favor of the state, it becomes a member of the United Nations. ${ }^{150}$ The requirements for joining the United Nations are not the same as the requirements for statehood. However, the United Nations will only accept entities that it considers to be states. ${ }^{151}$

Recognition by other states is policy-driven. ${ }^{152}$ While membership to the United Nations and meeting the criteria for statehood help a new state's case, an existing state is not required to recognize the new state (although states can be compelled not to recognize a state). ${ }^{153}$ If a seceding state can be recognized-whether by meeting the criteria for statehood or joining the United Nations-the secession will likely be accepted, and the new state will join its place in the international community.

\section{E. Sui Generis: An Alternative with Dangerous Precedent}

If recognition and the blessing of international or state law fail, there is another concept that could allow a seceding state to gain its independence: sui generis, "of its own kind." 154 The concept was famously used during the resolution of Kosovo's independence. The North Atlantic Treaty Organization (NATO), in violation of the United Nations Charter's provisions against the use of force, bombarded Serbia to halt human rights violations against Kosovan Albanians. ${ }^{155}$ NATO's actions presented international lawyers with a difficult decision: uphold the letter of international law and let innocent Kosovan Albanians die or ignore the Charter's prohibitions on force and save lives. ${ }^{156}$ Some international lawyers chose a third option: declare Kosovo to be sui generis, thus allowing for the nobility of stopping a human rights violation while simultaneously showing nominal respect to international law. ${ }^{157}$ Kosovo's declaration of independence was accepted with the

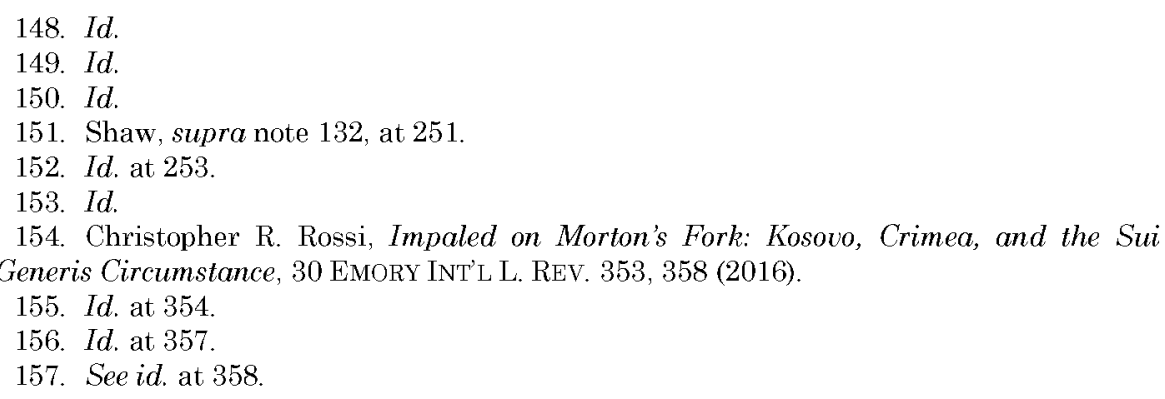


same logic. 158 Despite claims that a sui generis case would not set a precedent, 159 other cases will surely attempt to exploit it once it circumvents international law. Russia already used similar reasoning in its annexation of Crimea. ${ }^{160}$

The International Court of Justice, by contrast, refused to label Kosovo a sui generis case. ${ }^{161}$ The Court opted to examine Kosovo's declaration of independence under international law and set a precedent of its own: international law cannot be circumvented when it is convenient. ${ }^{162}$ Given the highly controversial nature of the Kosovo crisis, sui generis as a means of secession is technically possible but by far the most unlikely to succeed.

\section{F. "The South is My Country": International Secession}

With the law now explained, let us return to the hypothetical in which "The South is My Country" unilaterally secedes from Brazil. How will this secession fare under international law? As before, the prospects do not look promising for the southern movement.

Based on the above discussion and explanation, "The South is My Country's" situation is one of self-determination. Corruption and potential taxation without representation are certainly not ideal, but they do not meet the three cases in which a right to secession may be acknowledged. The southern states' colonial ties are to European nations who have long abandoned colonization-Germany and Italy. There is not alien subjugation outside a colonial context. Finally, there is no deprivation of internal self-determination, or at least none sufficient enough for international law. Given the lack of accepted contexts for secession, it is very likely international law would view "The South is My Country's" secession as illegal.

Hypothetically, suppose the separatist movement continued despite international law. The next step would be to obtain recognition and statehood.

"The South is My Country" currently meets two of the four factors of the Montevideo criteria; specifically, it has a defined territory and a permanent population. The movement has neither a government nor a majority of southern Brazilian support. Additionally, the southern states are wealthy, but there are a variety of functions that the south does not yet carry out. Unlike Catalonia, the southern states do not

158. Id.

159. Christakis, supra note 81 , at 81 .

160. Rossi, supra note 154 , at 359 .

161. Christakis, supra note 81 , at 81 .

162. Id. 
have much experience in autonomy, aside from a brief ten-year revolution.

Membership in the United Nations could be the easiest route for "The South is My Country." The initial requirement of accepting international law obligations is a fairly low bar. But, in this hypothetical, "The South is My Country" has illegally seceded, which would almost certainly cast doubt on its promise to follow international law. On the other hand, Brazil is not currently on the Security Council,163 (and neither is Spain) which would almost certainly vote against a separatist movement inspired by Catalonia. 164 However, Brazil's last term on the Security Council was in 2010-2011: Brazil has been a frequent member having served ten terms in the past, all roughly five years apart. ${ }^{165}$ There is a high probability Brazil could be appointed to the Security Council again in the near future. If Brazil could turn other members against "The South is My Country," the situation would not be good for the fledgling state. As for the General Assembly vote, most states arise out of humanitarian crises, and there would not be one here. ${ }^{166}$ Even Kosovo's humanitarian crisis did not guarantee its successful independence! If a clear human rights case like Kosovo can have a hard time, "The South is My Country's" lack of humanitarian issues would likely not receive sympathy or recognition from other states.

\section{CONCLUSION}

Even in the most generous circumstances available, "The South is My Country's" odds of seceding from Brazil are low. Brazilian law ensures that the separatist movement will not get very far. International law disfavors unilateral secession except for the most extreme situations. Achieving recognition and statehood is an inconsistent process with no clear indicators to project success. For now, all "The South is My Country" can do is poll its fellow Brazilians and see if other movements such as Catalonia can generate more interest in their movement. Perhaps the surge of nationalism will pass, or perhaps we will see an independent southern Brazil before the next century. Only time will tell.

163. See Current Members, United NATIONS SeCuRity Council http:/www.un.org/en /sc/members/ (last visited Oct. 5, 2018).

164. See id.

165. Countries Elected Members of the Security Council, United NATIONS SECURITY

COUNCIL http://www.un.org/en/sc/members/elected.asp (last visited Oct. 5, 2018).

166. Catalonia's Bid, supra note 47. 